\title{
Ready for new challenges - PeBeKa S.A.
}

\author{
This article presents the history and activities of Przedsiębiorstwo Budowy Kopaln \\ PeBeKa S.A., which celebrated its 60th anniversary in 2020. The range of activities and \\ skills that accompany the functioning of PeBeKa S.A. allowed them to be referred to as \\ the "KGHM Builders".
}

Key words: underground mining, mining works, construction works, deep drilling

\section{PRELUDE}

In 2020, Przedsiębiorstwo Budowy Kopalń PeBeKa S.A. proudly celebrated the $60^{\text {th }}$ anniversary of its existence on the market. On April $27^{\text {th }}, 1960$, PBKRM (later ZBRM, now Przedsiębiorstwo Budowy Kopalń PeBeKa S.A.) was founded with the purpose of the extraction of copper ore in the area between Lubin and Głogów in Lower Silesia. At that time, PBKRM was the general contractor of the largest copper ore mining complex in Europe. The degree of difficulty and the scale of the project was a huge challenge for the engineering staff and employees of the newly established enterprise. Over the last 60 years we have met these challenges and we can proudly define PeBeKa S.A. as the "KGHM Builders".

\section{INTRODUCTION}

Thanks to the knowledge and traditions passed down by subsequent generations of employees, PeBeKa S.A. is an enterprise providing services in the field of mining and construction work:

- mining shafts: sinking, maintenance and shut down,

- mining services,

- construction of mines: underground and on the surface,

- deep drilling,

- tunneling,

- construction work,

- conservation of historic mines.

To illustrate the range of activities of PeBeKa S.A. this article will describe the main undertakings of the company, along with a short presentation highlighting the technologies used. The value and success of PeBeKa S.A.'s work provides great results and rewards the trust that our clients have placed in us. The projects implemented by PeBeKa are in several dozen locations on five continents. From its inception, PeBeKa S.A. constructed 31 shafts for Polish copper mines and nearly 1.5 thousand kilometers of underground headings and drifts. In its history, PeBeKa has constructed several dozen tunnels - metro, rail, road and hydrotechnical. It was PeBeKa that undertook the construction of the metro in Warsaw in the 1980s. Drawing on tradition and great skills, PeBeKa S.A. contributed to the preservation of the history of Polish mining by conducting mining works in the historic Salt Mine in Wieliczka [1].

\section{MINING WORKS}

\subsection{Mining shafts}

To access the copper ore deposit in the Fore-Sudetic Monocline, it was necessary to create the requisite infrastructure and assemble the mining facilities and equipment. The first challenge faced by the crew of PBKRM was shaft sinking. The main barrier that made it difficult to reach the level of the ore layers was the geological conditions of the Copper Basin, which consisted of abundant waterlogging, the large depth of unstable sediments and their heterogeneous formation in terms of physical, mechanical and thermal properties. During the planning and design stage, the loose deposits of waterlogged sands, plastic clays and coal managed to achieve 
a water inflow reaching up to $30 \mathrm{~m}^{3} / \mathrm{min}$, and this posed (and still poses) a major challenge for PeBeKa employees. Striving to ensure safe working conditions that would allow for shaft sinking, PeBeKa employees mobilized to develop and improve their skills and technical ideas, which resulted in the intro- duction of shaft sinking by means of artificial ground freezing (AGF) in the 1960's. Used in KGHM mines, it is a unique solution both in terms of the depth and extent of freezing. The experience with AGF enabled our company to build all the shafts of the KGHM Mines.

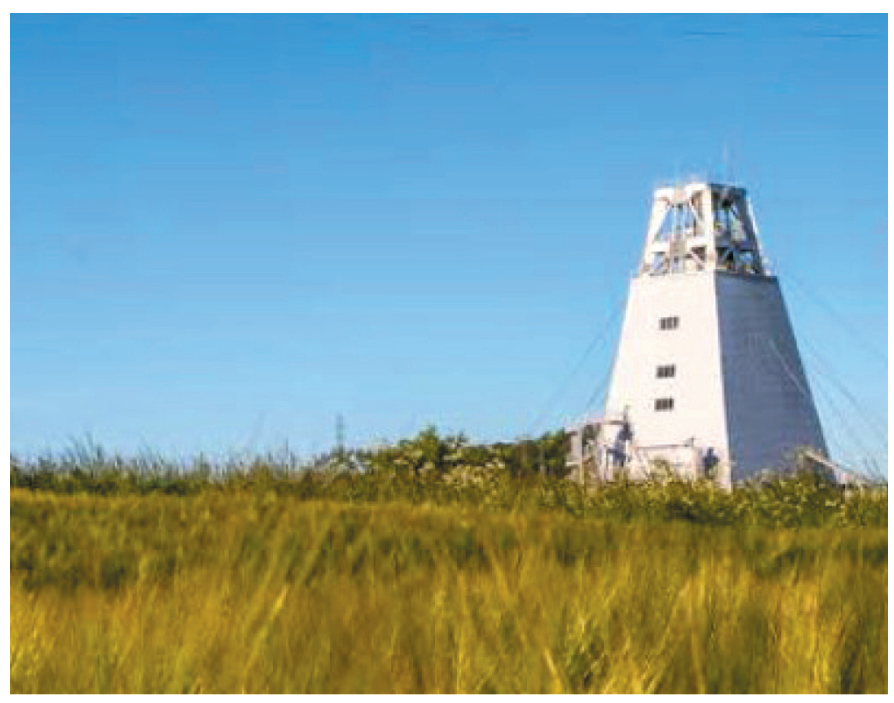

Fig. 1. GG-1 Shaft Tower

Now, the $31^{\text {st }}$ mining shaft for KGHM is under construction, with a record depth of $1351.0 \mathrm{~m}$ and a record freezing depth of $770 \mathrm{~m}$, the shaft diameter of the lining is $7.5 \mathrm{~m}$ [1] (Fig 1). The shafts made by PeBeKa have a complex structure and their final casing, depending on local hydrogeological conditions, can consist of: concrete casing, reinforced concrete casing and cast iron tubing (Fig 2). During the shaft sinking stage, carried out with the use of both blasting agents and mechanical mining, mining bolt linings with nets are formed.
Throughout the entire period of operation of the Company, the evolution of shaft sinking technology continues. It is thanks to the involvement of the engineering staff, employees and cooperation with scientific facilities that shaft sinking, as well as shaft maintenance, is carried out efficiently, safely and includes mining services, assembly and construction works. Thanks to our knowledge and skills, as well as our equipment and facilities, sinking shafts is still the pride of our company.

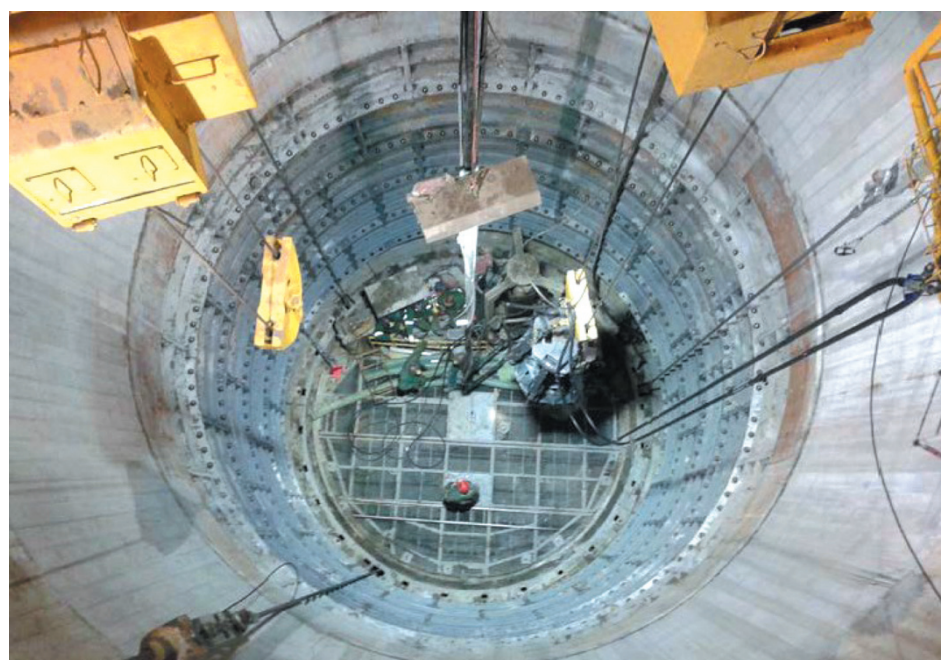

Fig. 2. Sinking the Shaft GG-1 for O/ZG "Polkowice-Sieroszowice" Mine 
PeBeKa specialists also participate in the liquidation of mining shafts. A very complicated process of the disassembly of all shaft equipment and installations has to be carried out, and water dams have to be built to cut off the mine workings from the shaft pipe, thus protecting the functioning part of the mining plant from potential water ingress. Thanks to the preparation of detailed documentation, the lining of the terminated shaft is made malleable, which is then filled with a specially selected material [2].

\subsection{Mining excavations}

Another area in which PeBeKa S.A. specializes is the construction of mining drifts to create the basic underground structure of the mining plant, enabling the commencement of the exploitation of the deposit (Fig. 3).
Nearly sixty years ago, the pioneers of Polish copper mining used hand-operated pneumatic tools to drill drifts and moved between areas of the mine on foot.

As technology progressed and new mechanical devices appeared, including self-propelled mining machines, the PeBeKa equipment fleet and the range of mining technologies was constantly expanding. At the moment, the company has a very well-equipped fleet enabling the construction of underground drifts by blasting the rock mass with explosives, as well as with mechanical mining of the rock mass.

In the vast majority of drifts, the walls and ceilings are secured with mining bolts, which are the basic form of support in KGHM's mining plants. Our mining technologies are not solely limited to mining bolt support, we also execute horizontal drifts secured with flexible support casings (Fig. 4) as well as implementing other technical solutions.

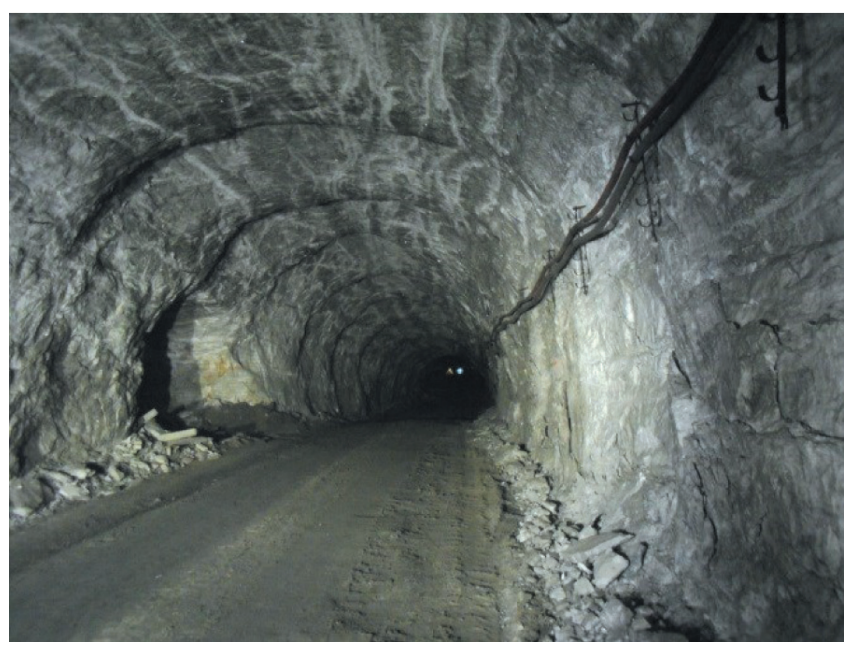

Fig. 3. Drift in the Salt Layer

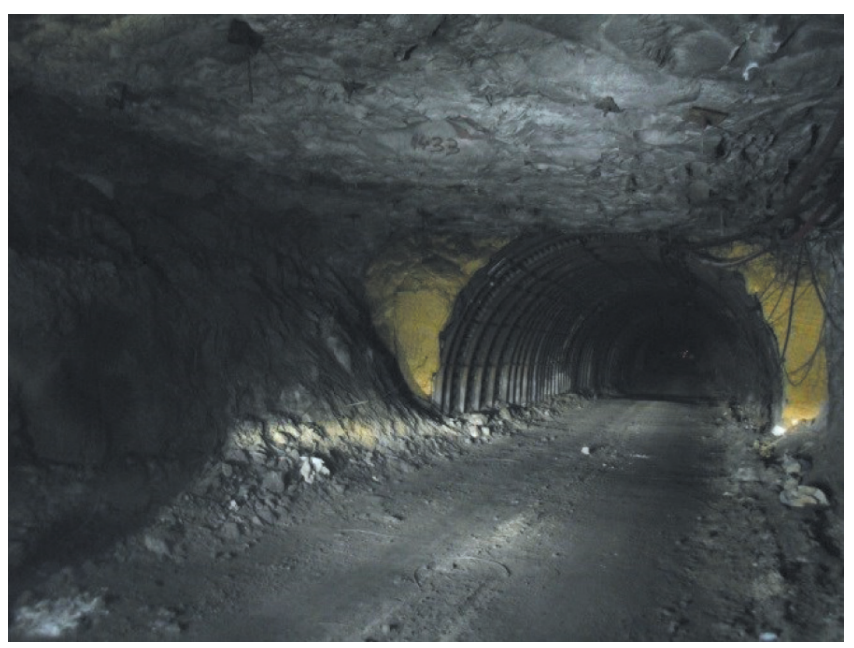

Fig. 4. Drift with Mine roadway supports and EKOFLEX - Mine Foam 
The PeBeKa crew made about $20 \mathrm{~km}$ of drifts with Roadheaders, which were also secured with mining bolt lining. Depending on the prevailing conditions, we use preemptive merging injections. As already mentioned, the PeBeKa team has carried out mining works on five continents, and it is this experience that makes us constantly raise the bar of the difficulty of the tasks we perform.

It is precisely this type of challenge that is currently being carried out on a project involving the con- struction of a new underground ore bunker, and the modernization of an existing, functioning underground ore bunker. The task is being carried out in the immediate vicinity of an active mining shaft, and the constantly operating equipment and facilities of the mining plant. Only thanks to the involvement of the employees and the equipment fleet was the task carried out without any unnecessary downtime and the level of work safety and work quality at a very high degree [2].

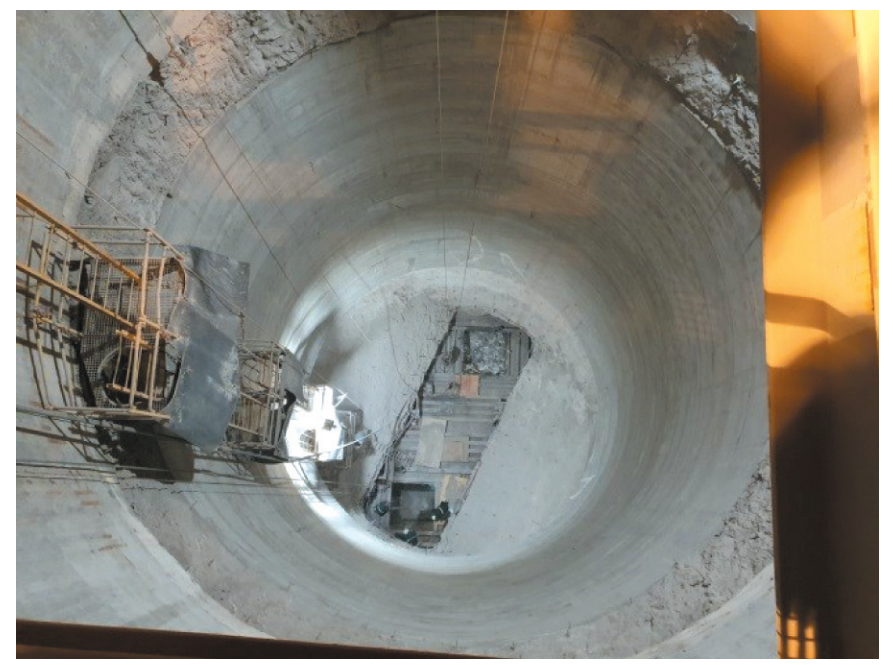

Fig. 5. Construction works in Ore Bunker

\section{ASSEMBLY WORKS}

The functioning of a mining plant is characterized by continuous change. The mine develops, expands its area of operation, and finally closes down after the end of its operation. In each of the main stages of the mining plant operation period, it is necessary to perform tasks whose unique traits are well known to PeBeKa.

Along with reaching for lower and lower parts of the copper ore deposits, new challenges arise that PeBeKa has to face. As part of our skills, we make various types of underground facilities, devices and installations that enable the operation of underground mining plants. In order to ensure the proper working conditions in the underground workings located at depths exceeding 1,200 m, it was necessary to build an air-conditioning system. At the beginning of the 21st century, this was the challenge that PeBeKa engineers faced. The result of their hard work and cooperation with contractors is the central air conditioning system in the Rudna Mine [2]. The cooling system for underground workings operates by utilizing 'ice water' at a temperature of $1.5^{\circ} \mathrm{C}$, which is produced by the two air-conditioning stations on the surface. Chilled water is brought in from the mining station with the use of shaft pipelines and pipelines built into large-diameter holes in the rock mass. The underground part of the system includes a three-chamber feeder, pumping station, main pipelines, controlling and measuring equipment and air coolers.

In the past, PeBeKa has built a lot of facilities, such as: underground machinery operation chambers, belt conveyors with a total length of more than $100 \mathrm{~km}$, ore bunkers and transformer chambers. Each of these objects is a very important element of the mining plant and their execution requires a large amount of knowledge and skill.

The vast majority of the implemented facilities have been commissioned by the user, which means that the works were performed in the "turn-key" formula. In 2015, using the formula "design-build" PeBeKa S.A., got to modernize a nearly thirty-year-old shaft. The modernization of the shaft also involved a change in its function. Without stopping the functioning of the mining plant, PeBeKa employees carried out a very complicated process of chang- 
ing the function of the mining shaft. The functioning air-intake shaft was transformed into a material, people and equipment hoisting and air-intake shaft. Such a function change is a very complex process, involving:

- assembly works:

- reconstruction of the Shaft Tower,

- assembly and installation of hoisting devices,

- shaft reinforcement,

- assembly and installation of electrical and telecommunication devices, etc.

- mining works:

- reconstruction of the shaft bottom,

- construction works:

- erecting buildings related to the new functions of the shaft.

\section{DEEP DRILLING \\ AND CONSTRUCTIONS WORKS}

The analysis of the demand for specialized mining services prompted the authorities of PeBeKa to create another branch whose task is to provide drilling services. The technical staff, crew and their drilling equipment perform a number of drilling works in our country, related to the identification of mineral deposits, as well as the search for geothermal water deposits.

To ensure the comprehensive execution of complex tasks, within the PeBeKa structure is also a branch whose task is conducting construction work. The range of services provided by this branch is very wide, and includes industrial, housing and communication construction.

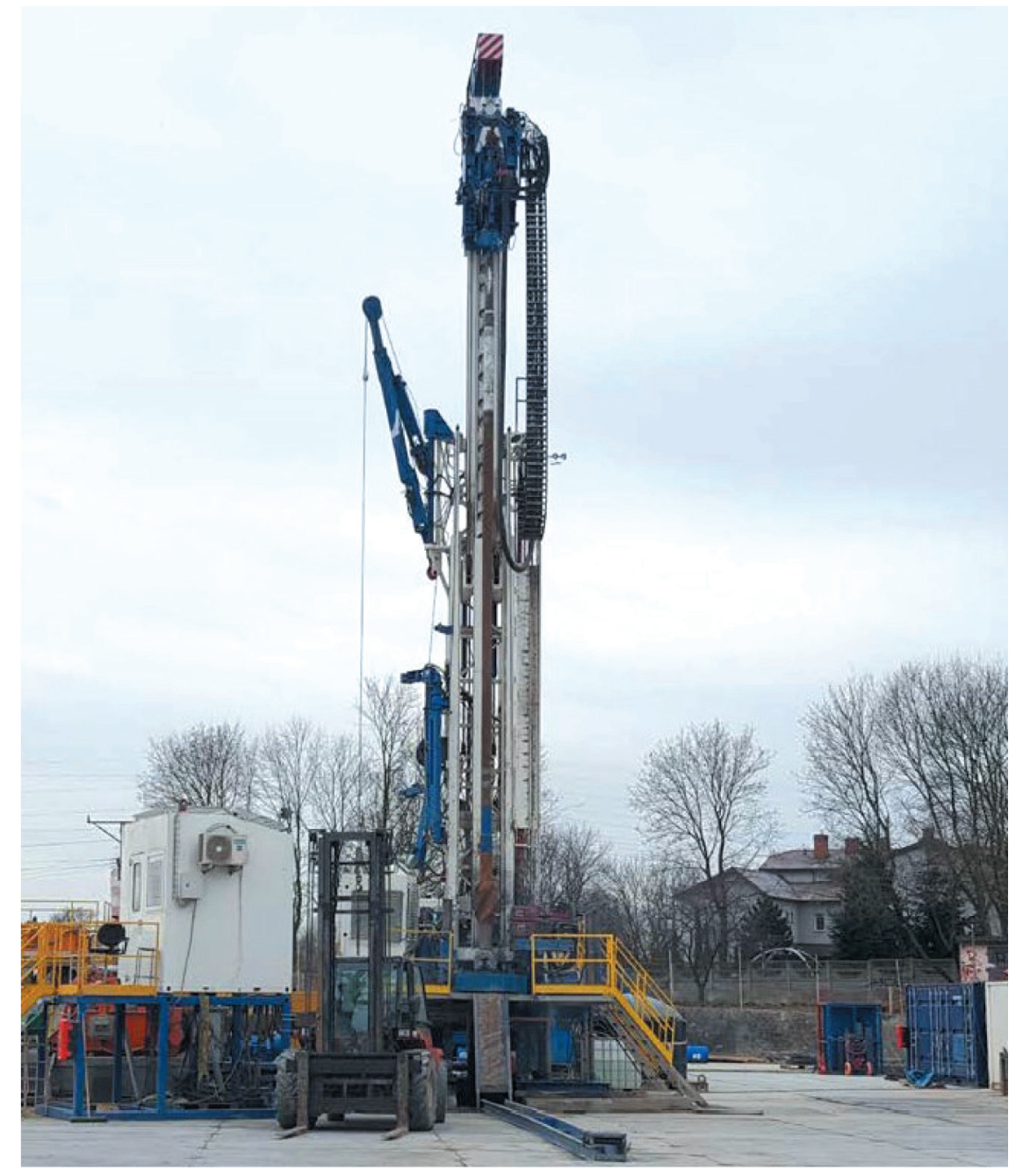

Fig. 6. Geothermal borehole - Tomaszów Mazowiecki

\section{SUMMARY}

A willingness to face new challenges, and the constant development of technology has accompanied our employees, thanks to which PeBeKa S.A. has achieved so much in its great history and continues to grow. It is worth emphasizing that PeBeKa boasts over $1600 \mathrm{~km}$ of underground drifts. 
It is also worth noting the safe working conditions for the PeBeKa S.A. staff which are of superior value. The commitment of the management and staff was appreciat- ed by the "Bezpieczne Górnictwo" Foundation of Professor Wacław Cybulski in December 2019, by awarding PeBeKa a prize in the "Safe Branch" competition (Fig. 7).

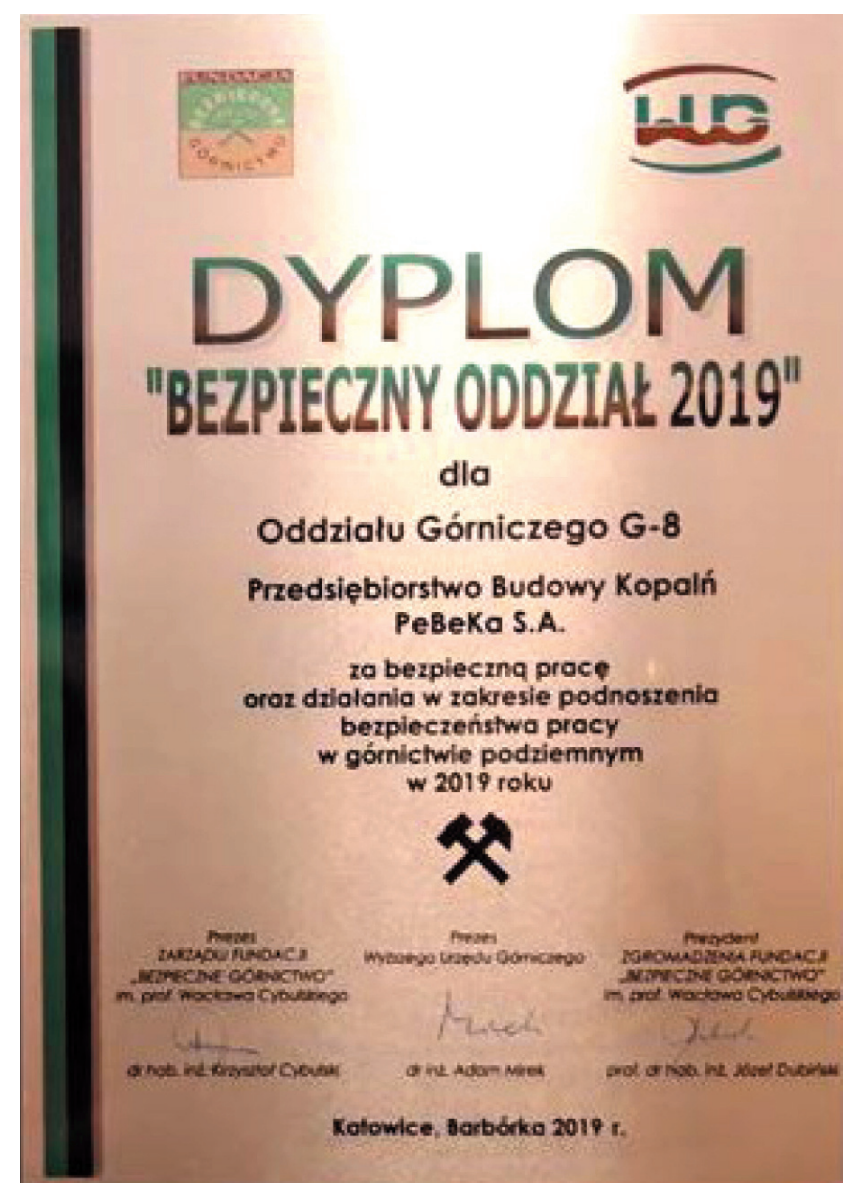

Fig. 7. "Safe Branch" diploma for PeBeKa S.A.

[1] PeBeKa S.A.: Czerpiemy z tradycji, stawiamy na przyszłość Kronika 50-lecia PeBeKa S.A., Lubin 2010.

[2] PeBeKa S.A.: Kronika PeBeKa 1960-2020. Cel - Ludzie Technologia, Lubin 2020.

ul. Marii Sklodowskiej-Curie 76, 59-300 Lubin, Poland dominik.leszczuk@pebeka.com.pl 


\title{
Gotowi na nowe wyzwania - PeBeKa S.A.
}

\author{
Artykut prezentuje rys historyczny i zakres dziatalności Przedsiębiorstwa Budowy Ko- \\ palń PeBeKa S.A., które w 2020 roku obchodzito 60. jubileusz funkcjonowania. Zakres \\ działalności i umiejętności, które towarzysza funkcjonowaniu PeBeKa S.A., pozwolito \\ na określane firmy mianem „budowniczych KGHM”.
}

Słowa kluczowe: górnictwo podziemne, roboty górnicze, roboty budowlane, wiercenia powierzchniowe

\section{WSTĘP}

W 2020 roku Przedsiębiorstwo Budowy Kopalń PeBeKa S.A. obchodziło jubileusz 60 lat istnienia na rynku. 27 kwietnia 1960 roku zostało utworzone Przedsiębiorstwo Budowy Kopalń Rud Miedzi (PBKRM), którego celem było uruchomienie wydobycia rud miedzi w obszarze między Lubinem a Głogowem na Dolnym Śląsku. To właśnie PBKRM było generalnym wykonawcą planowanego na ówczesne czasy największego w Europie kompleksu wydobywczego rud miedzi. Stopień trudności i skala przedsięwzięcia stanowiły ogromne wyzwanie dla kadry inżynieryjnej i pracowników nowo powstałego przedsiębiorstwa. Wyzwaniom tym sprostano i PeBeKa S.A. można określić mianem „budowniczych KGHM”.

\section{WPROWADZENIE}

Dzięki wiedzy i tradycjom przekazywanym z pokolenia na pokolenie PeBeKa S.A. jest przedsiębiorstwem świadczącym usługi w zakresie robót górniczych oraz budowalnych:

- drążenie, zbrojenie, utrzymanie i likwidacja szybów górniczych,

- drążenie wyrobisk podziemnych,

- budowa kompletnej infrastruktury zakładów górniczych zarówno w wyrobiskach dołowych, jak i na powierzchni,

- roboty wiertnicze zarówno powierzchniowe, jak i dołowe,

- drążenie tuneli różnego przeznaczenia,

- budownictwo przemysłowe i kubaturowe,

- konserwacja zabytkowych obiektów górniczych.

Aby zobrazować zakres działalności PeBeKa S.A., w niniejszym artykule opisane zostaną główne kierun- ki działalności wraz z krótkim przedstawieniem stosowanych technologii. O wartości pracy PeBeKa S.A. świadczą efekty oraz zaufanie, jakim obdarzyli nas klienci. Mapę zrealizowanych przez PeBeKa projektów tworzy kilkadziesiąt lokalizacji na pięciu kontynentach. Od początku istnienia PeBeKa S.A. wykonało wszystkie trzydzieści szybów dla polskich kopalni miedzi oraz blisko 1,5 tysiąca kilometrów podziemnych chodników i przekopów. W swojej historii PeBeKa wykonało kilkadziesiąt tuneli - metra, kolejowych, drogowych i hydrotechnicznych. To właśnie PeBeKa podjęło się latach 80 . XX wieku realizacji metra w Warszawie. Czerpiąc z tradycji i posiadając ogromne umiejętności, PeBeKa S.A. przyczyniło się do zachowania historii polskiego górnictwa przez prowadzenie robót górniczych w zabytkowej Kopalni Soli w Wieliczce [1].

\section{ROBOTY GÓRNICZE}

\subsection{Szyby górnicze}

Udostępnienie zalegającego w Monoklinie Przedsudeckiej złoża rud miedzi wymagało stworzenie niezbędnej infrastruktury, obiektów i urządzeń górniczych. Pierwszym wyzwaniem, któremu przyszło stawić czoło załodze ówczesnego PBKRM, było głębienie szybów. Główną barierą utrudniającą w prosty sposób osiągnięcie poziomu warstw rudnych były warunki geologiczne Zagłębia Miedziowego, na które składały się obfite zawodnienie, duża głębokość zalegania osadów niestatecznych oraz niejednorodne ich wykształcenie pod względem właściwości fizycznych, mechanicznych i termicznych. To właśnie luźne utwory zawodnionych piasków, plastycznych iłów i węgli $\mathrm{z}$ dopływem wody osiągającym na etapie badań projektowych nawet $30 \mathrm{~m}^{3} / \mathrm{min}$ stanowily i nadal stanowia 
wyzwanie dla pracowników PeBeKa. Dążenie do zapewnienia bezpiecznych warunków pracy umożliwiających drążenie szybów mobilizowało pracowników firmy do rozwoju i doskonalenia umiejętności oraz myśli technicznej, czego skutkiem było wprowadzenie jeszcze w latach 60. ubiegłego wieku głębienia szybów za pomocą mrożenia górotworu. Metoda zastosowana w kopalniach KGHM stanowi unikatowe rozwiązanie zarówno pod względem głębokości, jak i zasięgu mrożenia. Doświadczenia z mrożeniem górotworu umożliwiły naszemu przedsiębiorstwu wykonanie wszystkich szybów Zagłębia Miedziowego. Aktualnie jest wykonywany trzydziesty pierwszy szyb górniczy dla KGHM o rekordowej głębokości wynoszącej 1351,0 m oraz rekordowej głębokości mrożenia się-gającej $770 \mathrm{~m}$, średnica szybu w świetle obudowy to 7,5 m (rys. 1) [1]. Szyby wykonane przez PeBeKa posiadają złożoną konstrukcje, a ich obudowę ostateczną w zależności od lokalnych warunków hydrogeologicznych stanowią: obudowa betonowa, obudowa żelbetowa, obudowa z tubingów (rys. 2). Na etapie drążenia prowadzonego zarówno z wykorzystaniem środków strzałowych, jak i urabiania mechanicznego obudowę wstępną wyrobiska stanowi obudowa kotwowa wraz z siatkami.

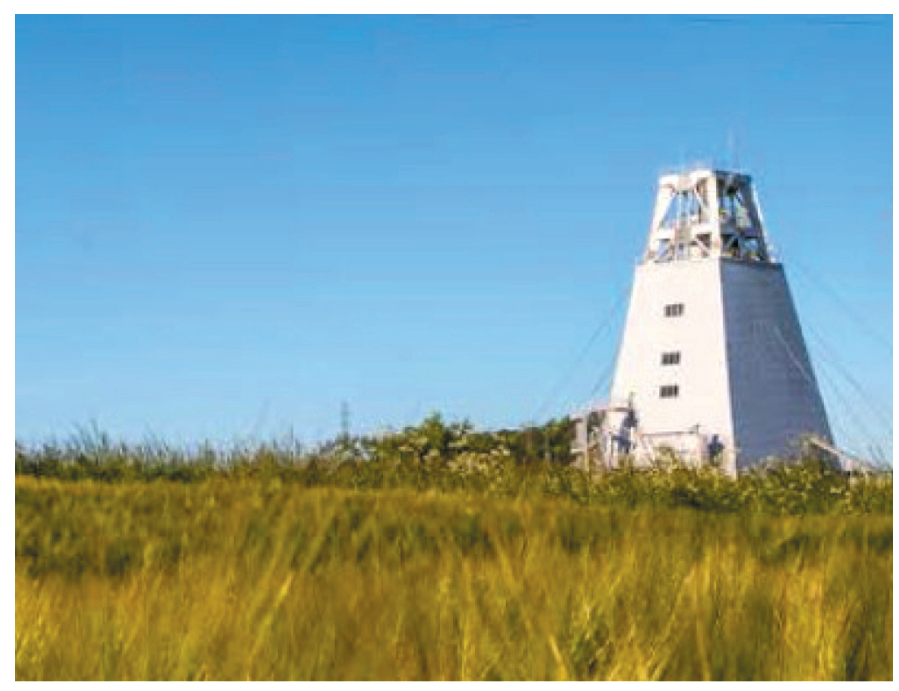

Rys. 1. Wieża szybowa szybu GG-1

Przez cały okres funkcjonowania firmy rozwijana jest technologia głębienia szybów. To właśnie dzięki zaangażowaniu kadry inżynieryjnej, pracowników oraz współpracy z zapleczem naukowym głębienie szybów, a także ich konserwacja są prowadzone efek- tywnie i bezpiecznie. Ich zakres obejmuje roboty górnicze, montażowe i budowlane. Posiadana wiedza i umiejętności oraz zaplecze sprzętowe sprawiają, że drążenie szybów stanowi ważny obszar działalności przedsiębiorstwa.

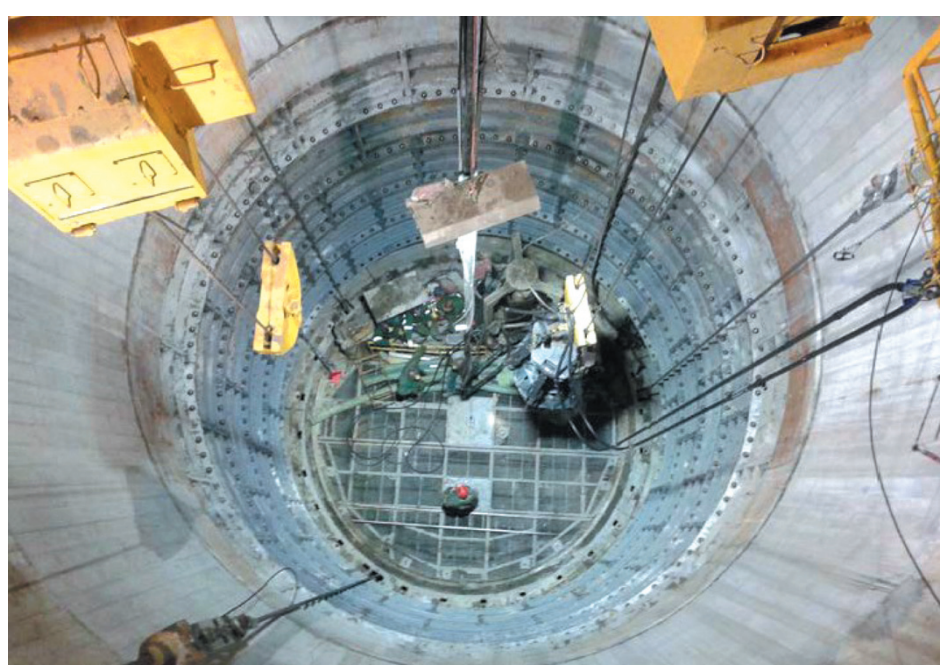

Rys. 2. Drażony szyb GG-1 dla O/ZG Polkowice-Sieroszowice 
Specjaliści PeBeKa uczestniczyli również w likwidacji szybów górniczych. Przeprowadzono bardzo skomplikowany proces demontażu urządzeń i instalacji szybowych, wybudowano tamy wodne odcinające wyrobiska dołowe od rury szybowej, zabezpieczając tym samym funkcjonującą część zakładu górniczego przed możliwością wdarcia się wody. Dzięki opracowaniu szczegółowej dokumentacji przeprowadzono upodatnienie obudowy likwidowanego szybu, który został wypełniony specjalnie dobranym materiałem [2].

\subsection{Wyrobiska górnicze}

Kolejnym obszarem, w którym specjalizuje się PeBeKa S.A., jest wykonywanie wyrobisk chodnikowych służących stworzeniu podstawowej struktury podziemnej zakładu górniczego umożliwiającej rozpoczęcie eksploatacji złoża (rys. 3). Pionierzy polskiej miedzi blisko sześćdziesiąt lat temu do drążenia wy- robisk używali ręcznych narzędzi pneumatycznych, przemieszczali się pomiędzy rejonami prowadzonych robót na piechotę.

$\mathrm{W}$ miarę postępu techniki i pojawiania się nowych urządzeń mechanicznych, w tym samojezdnych maszyn górniczych, park maszynowy PeBeKa i zakres technologii górniczych stale się powiększał. W tej chwili przedsiębiorstwo dysponuje bardzo bogato wyposażonym parkiem maszynowym umożliwiającym wykonywanie podziemnych wyrobisk chodnikowych $\mathrm{z}$ zastosowaniem urabiania górotworu materiałem wybuchowym, jak również z zastosowaniem mechanicznego urabiania górotworu.

W większości wykonywane są wyrobiska, których ociosy i stropy są zabezpieczone obudową kotwową. Jest ona obudową podstawową w zakładach górniczych KGHM. Technologie górnicze firmy nie ograniczają się tylko do obudowy kotwowej, realizuje ona również wyrobiska poziome zabezpieczone obudową podatną podporową (rys. 4), a także inne rozwiązania technicznymi.

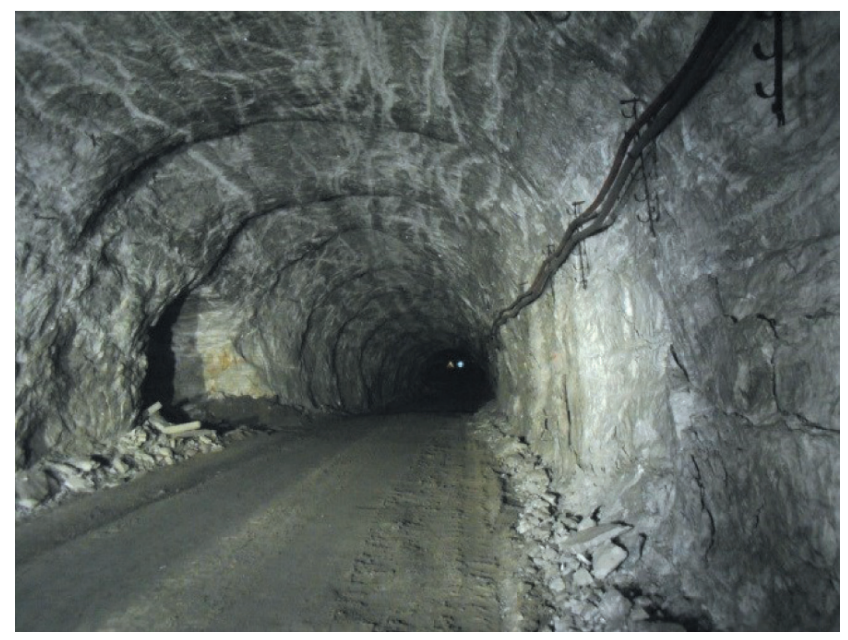

Rys. 3. Wyrobisko drażone w poktadzie soli

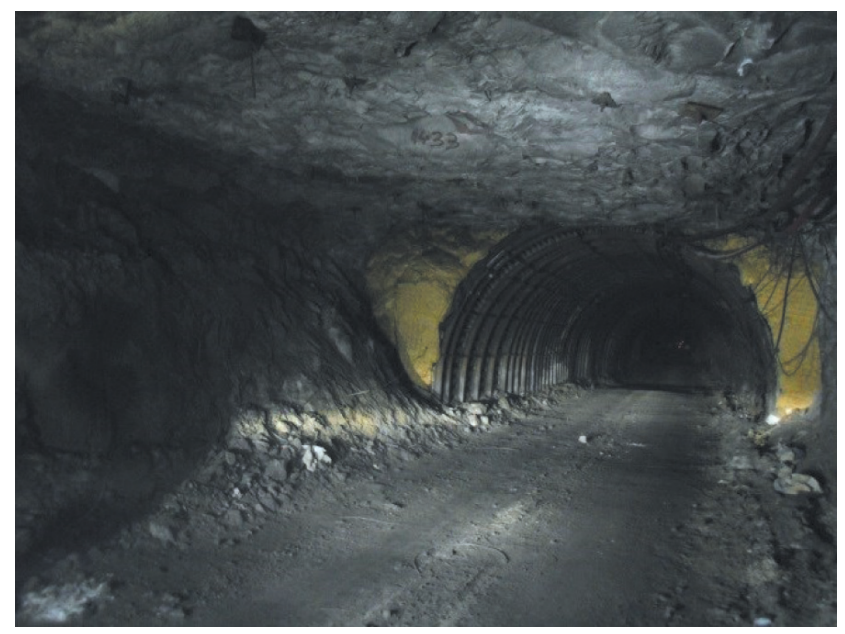

Rys. 4. Wyrobisko w obudowie podatnej z wyktadka EKOFLEX 
Dzięki prowadzeniu robót czterema kombajnami chodnikowymi zdobyliśmy cenne doświadczenia w mechanicznym urabianiu górotworu. Wykonane zostało blisko $20 \mathrm{~km}$ wyrobisk chodnikowych, które również zostały zabezpieczone obudową kotwową. W zależności od panujących warunków stosujemy scalające iniekcje wyprzedzające. Jak już wcześniej zostało napisane, załoga PeBeKa realizowała roboty górnicze na pięciu kontynentach i właśnie te doświadczenia sprawiają, że nie obawiamy się realizowania coraz trudniejszych zadań.
Właśnie tego typu wyzwaniem jest prowadzone obecnie zadanie obejmujące wykonanie nowego i modernizację funkcjonującego retencyjnego, podziemnego zbiornika urobku. Zadanie prowadzone jest $\mathrm{w}$ bezpośrednim sąsiedztwie (rys. 5) czynnego szybu wydobywczo-zjazdowego i stale funkcjonujących urządzeń i obiektów zakładu górniczego. Tylko dzięki zaangażowaniu pracowników i nowoczesnemu parkowi maszynowemu zadanie realizowane jest bez zbędnych przestojów a bezpieczeństwo prac i jakość robót stoją na bardzo wysokim poziomie [2].

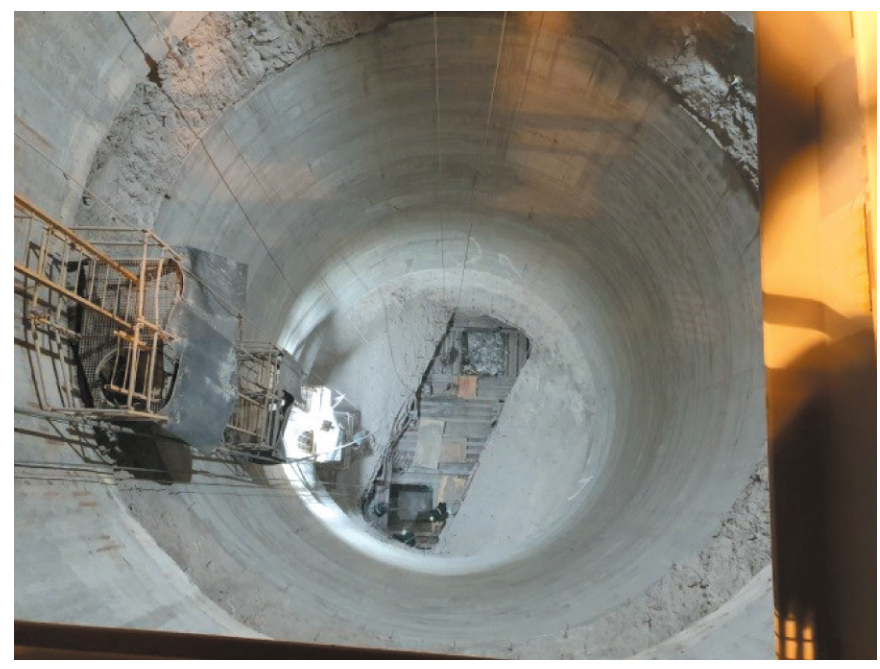

Rys. 5. Zbiornik urobku na etapie robót górniczych

\section{ROBOTY MONTAŻOWE}

Wraz z sięganiem po coraz niżej położone partie złoża rud miedzi pojawiają się kolejne wyzwania, którym naprzeciw wychodzi PeBeKa. Firma wykonuje różnego rodzaju podziemne obiekty, urządzenia i instalacje, które umożliwiają prowadzenie ruchu podziemnych zakładów górniczych. W celu zapewnienia właściwych parametrów środowiska pracy w wyrobiskach dołowych położonych na głębokościach przekraczających $1200 \mathrm{~m}$ konieczne stało się wybudowanie systemu klimatyzacji. Na początku XXI wieku $\mathrm{z}$ właśnie takim wyzwaniem zmierzyli się inżynierowie PeBeKa. Efektem ich wytężonej pracy, współpracy z kontrahentami stała się funkcjonująca na terenie O/ZG Rudna klimatyzacja centralna [2]. Zastosowano system chłodzenia wyrobisk dołowych $\mathrm{z}$ wykorzystaniem wody lodowej o temperaturze $1,5^{\circ} \mathrm{C}$ wytwarzanej w dwóch stacjach klimatyzacyjnych na powierzchni. Woda lodowa sprowadzana jest $\mathrm{z}$ wyrobisk zakładu górniczego z wykorzystaniem rurociągów szybowych oraz rurociągów zabudowanych $\mathrm{w}$ otworach wielko- średnicowych w górotworze. W skład podziemnej części systemu wchodzi podajnik trójkomorowy, przepompownia, rurociagi magistralne, aparatura sterująca i pomiarowa oraz chłodnice powietrza. $\mathrm{W}$ miejscach bardzo oddalonych zabudowane zostały maszyny klimatyzacyjne, które wykorzystują wodę lodową z obiegu powrotnego [2].

W minionych latach PeBeKa wykonało szereg obiektów takich jak: komory eksploatacji maszyn dołowych, przenośniki taśmowe o łącznej długości przekraczającej $100 \mathrm{~km}$, zbiorniki retencyjne, komory transformatorowe. Każdy z tych obiektów jest bardzo ważnym elementem zakładu górniczego, a ich budowa wymagała dużego zasobu wiedzy i umiejętności.

Zdecydowana większość realizowanych obiektów została oddana użytkownikowi do eksploatacji, co oznacza, że roboty wykonane zostały w formule „pod klucz”. W formule „zaprojektuj - wybuduj” PeBeKa S.A. w 2015 roku otrzymało zlecenie modernizacji blisko trzydziestoletniego szybu. Modernizacja szybu wiązała się z również ze zmianą jego funkcji. Bez zaburzenia funkcjonowania zakładu górniczego pracow- 
nicy PeBeKa przeprowadzili skomplikowany proces zmiany funkcji szybu górniczego. Funkcjonujący szyb wdechowy został przekształcony w szyb materiałowo-zjazdowy. Taka zmiana funkcji jest procesem bardzo skomplikowanym, obejmującym:

- roboty montażowe:

- przebudowa wieży szybowej,

- zabudowa urządzeń wyciągowych,

- zbrojenie szybu,

- zabudowa urządzeń i instalacji elektrycznych, telekomunikacyjnych itp.

- roboty górnicze:

- przebudowa podszybia,

- roboty budowlane,

- wzniesienie obiektów budowlanych związanych z nowymi funkcjami szybu.

\section{ROBOTY WIERTNICZE \\ I ROBOTY BUDOWLANE}

Prowadzona analiza zapotrzebowania na specjalistyczne usługi górnicze skłoniła władze PeBeKa do utworzenia kolejnego oddziału, którego zadaniem jest świadczenie usług wiertniczych. Posiadana kadra techniczna, załoga i sprzęt wiertniczy wykonuje na terenie naszego kraju szereg robót wiertniczych związanych z rozpoznaniem złóż kopalin, a także poszukiwaniem złóż wód geotermalnych (rys. 6).

W celu zapewnienia kompleksowej realizacji zadań w strukturze PeBeKa znajduje się również oddział, którego zadaniem jest prowadzenie robót budowlanych. Zakres świadczonych usług jest bardzo szeroki i obejmuje budownictwo przemysłowe, komunikacyjne oraz kubaturowe.

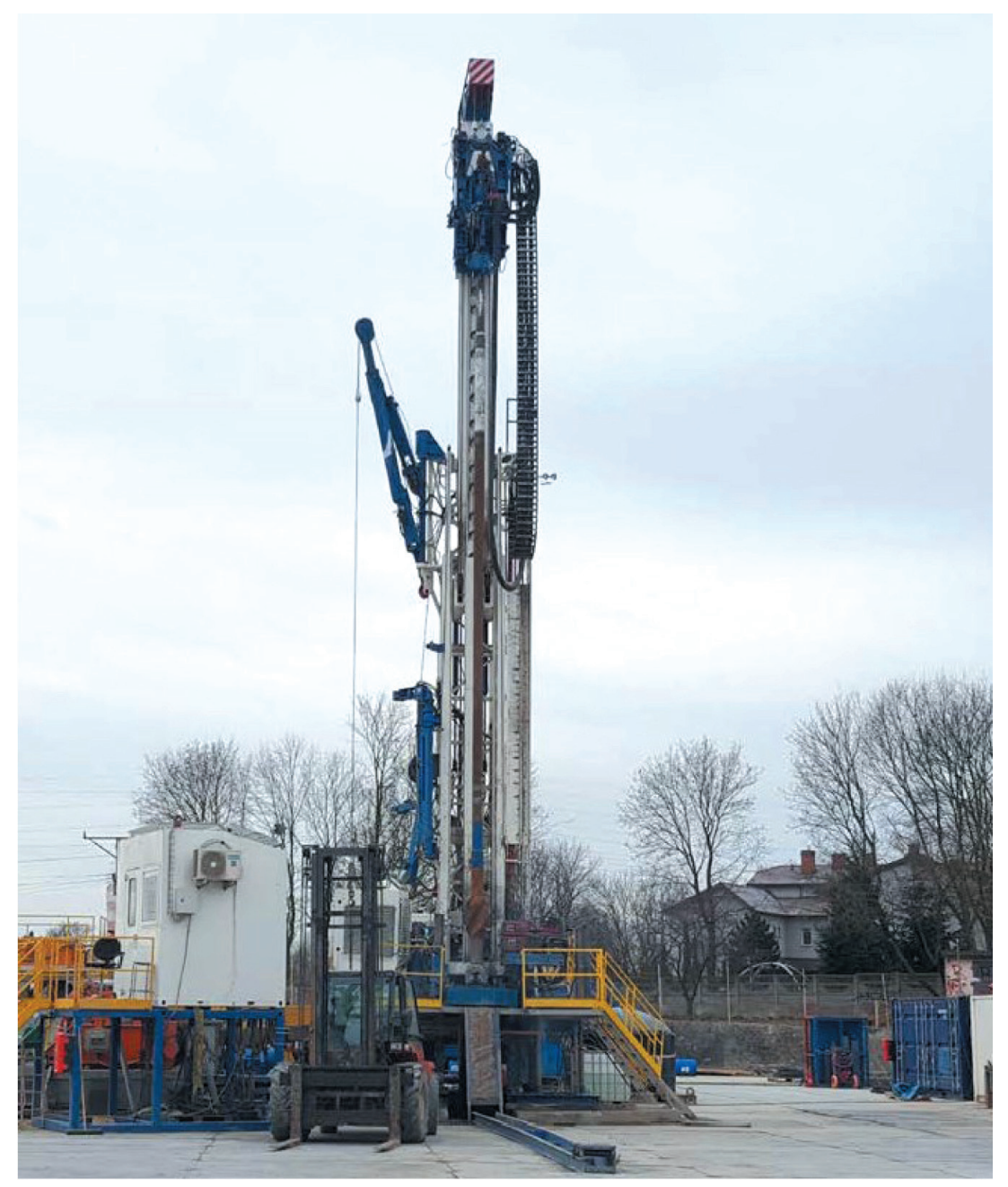

Rys. 6. Odwiert geotermalny w Tomaszowie Mazowieckim

\section{PODSUMOWANIE}

Chęć stawiania czoła nowym wyzwaniom, stały rozwój techniki i technologii stale towarzyszyły i nadal towarzy- szą pracownikom, dzięki czemu PeBeKa S.A. osiągnęła tak wiele i nadal się rozwija. Wart podkreślenia jest fakt, że PeBeKa może pochwalić się wykonaniem ponad $1600 \mathrm{~km}$ wyrobisk podziemnych. Stworzenie 
bezpiecznych warunków pracy załogi PeBeKa S.A. jest wartością nadrzędną. Zaangażowanie kierownictwa i załogi zostało docenione przez Fundację „Bezpiecz- ne Górnictwo" im. prof. Wacława Cybulskiego w grudniu 2019 roku, która przyznała PeBeKa nagrodę w kolejnej edycji konkursu „Bezpieczny Oddział” (rys. 7).

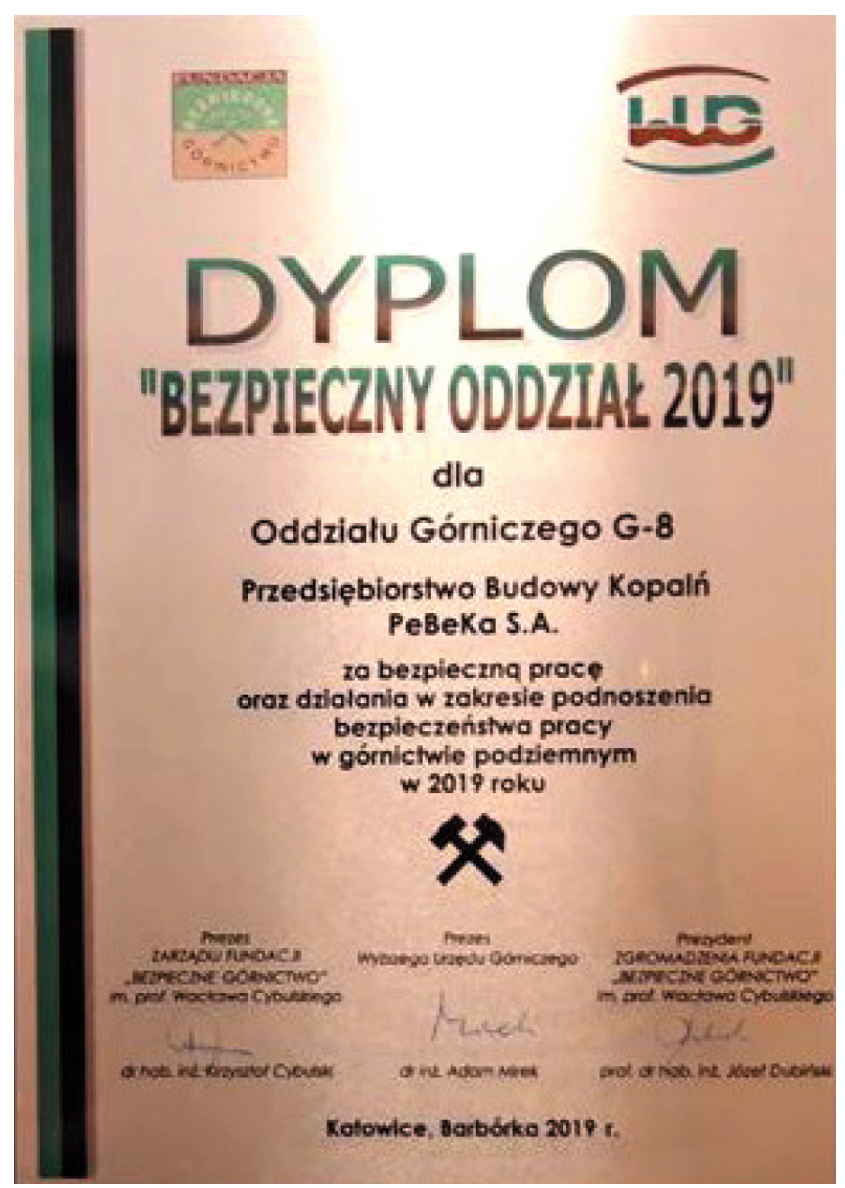

Rys. 7. Dyplom „Bezpieczny Oddział” dla PeBeKa S.A.

[1] PeBeKa S.A.: Czerpiemy z tradycji, stawiamy na przysztość Kronika 50-lecia PeBeKa S.A., Lubin 2010.

[2] PeBeKa S.A.: Kronika PeBeKa 1960-2020. Cel - Ludzie Technologia, Lubin 2020.

ul. Marii Skłodowskiej-Curie 76, 59-300 Lubin dominik.leszczuk@pebeka.com.pl 